\title{
Productivity, Water Use Efficiency and Economics of Indian Mustard (Brassica juncea L.) as Influenced by Integrated Nutrient Management
}

\author{
Rahul Ranjan $^{1 *}$, Sushil Dimree ${ }^{1}$, R.K. Pathak ${ }^{1}$, U.D. Awasthi ${ }^{2}$ and \\ Amar Kant Verma ${ }^{2}$ \\ ${ }^{1}$ Department of Soil Science and Agricultural Chemistry, ${ }^{2}$ Department of Soil Conservation \\ and Water Management, C S Azad University of Agriculture and Technology, Kanpur, India \\ *Corresponding author
}

\begin{tabular}{l} 
K e y w o r d s \\
$\begin{array}{l}\text { Indian mustard, } \\
\text { Integrated nutrient } \\
\text { management, FYM, } \\
\text { B:C ratio }\end{array}$ \\
Article Info \\
$\begin{array}{l}\text { Accepted: } \\
15 \text { October } 2018 \\
\text { Available Online: } \\
10 \text { November } 2018\end{array}$ \\
\hline
\end{tabular}

A B S T R A C T
A field experiment was carried out in the pot culture of Soil Science and Agricultural Chemistry, C S Azad University of Agriculture \& Technology during 2017-18. The experiment consisted of 9 treatments viz. $\mathrm{T}_{1}$ : Control, $\mathrm{T}_{2}$ : N (RDN 100\%), $\mathrm{T}_{3}$ : NP (100\%), $\mathrm{T}_{4}: \mathrm{NPK}(100 \%) \mathrm{T}_{5}: \mathrm{NPK}(100 \%)+\mathrm{Zn}_{5}, \mathrm{~T}_{6}: \mathrm{NPK}(100 \%)+\mathrm{S}_{30}, \mathrm{~T}_{7}: \mathrm{NPK}(100 \%)+\mathrm{Zn}_{5}+$ $\mathrm{S}_{30}, \mathrm{~T}_{8}: 75 \%(\mathrm{RDF})+\mathrm{Zn}_{5}+\mathrm{S}_{30}+25 \%$ through FYM and $\mathrm{T}_{9}: 75 \%(\mathrm{RDF})+\mathrm{Zn}_{5}+\mathrm{S}_{30}+$ $25 \%$ through FYM + PSB @ $2.5 \mathrm{Kg} \mathrm{ha}^{-1}$ in soil assigned in randomized block design replicated thrice during rabi season of 2017-18. The mustard cv Varuna was used in the experiment. The soil of the experimental plot was sandy loam in texture, medium in fertility and slightly alkaline in reaction. The weather during the experimental period was by and large normal and devoid of any extreme conditions. The results indicated that application of $75 \%$ (RDF) supplemented with $5 \mathrm{~kg} \mathrm{Zn,} 30 \mathrm{~kg} \mathrm{~S}$ along with remaining $25 \%$ through FYM and PSB @ $2.5 \mathrm{Kg} \mathrm{ha}^{-1}$ resulted in significantly maximum plant height, number of functional leaves, number of branches plant ${ }^{-1}$, girth of plant, root development, minimum water use and ultimately higher seed yield and WUE as compared to other corresponding tested treatments. The treatment also excelled in harvest index, net return and benefit: cost ratio under control.

\section{Introduction}

India has 2.6 per cent of world's geographical area and 4 per cent of its water resources to sustain 16.8 per cent of the world's population and more than 15 per cent of world's livestock. An increase in productivity has been the foremost objective of all agricultural developmental programmes in the last few decades. At the national level, we have increased our production from about 50 million tons in the early fifties to more than 284 million tonnes. The country's population is expected to reach around 1390 million by 2025 AD. To meet the food demand of growing population, food grain production has to be increased to 350 million tons by 2025 AD. The mining of nutrients from soil due to growing population with increasing food demand for ages severely limits crop 
production. The present day agriculture has become much more dependent upon fertilizers to produce more from shrinking land resources. In India, area and production of rapeseed mustard was 6.41 million hectares and 6.33 million tonnes during 2017-18. Indiscriminating exploitation of soil resources without considering the carrying capacity and non-judicious use of agricultural input to fetch higher production had generated serious problem on sustaining agricultural productivity and soil quality in a long run. Soil quality has to function within ecosystem boundaries to sustain biological productivity, maintain environment, quality and promote plant and animal health. Fertilizer management issue in crop production is drawing attention among farmers, especially under current climate change situation. Efficient fertilizer management under environment-friendly condition is crucial to increase crop production worldwide. Appropriate amount of fertilizers applied on to soils reduced greenhouse gas emissions, $\mathrm{NO}_{3}$ leaching and eutrophication.

Integration of chemical fertilizers with organic manures has been found quite promising not only in sustaining the soil health and productivity but also in stabilizing the crop production in comparison to the use of each component separately. Farm yard manure rich in organic matter can be supplemented with NPK fertilizers. Although, it is expensive than chemical fertilizer on nutrient basis but other beneficial effect which it has on soil can compensate for the added cost. It not only provides most of the essential nutrients but also improves soil structure through binding effect on soil aggregates (Kumawat et al., 2018). Keeping in view of declining productivity, it is apparent that there is need to generate more information on integrated nutrient management for oilseeds especially mustard for sustainable productivity. Hence, present investigation was undertaken to evaluate the effect of INM in integration of FYM and biofertilizer on growth and yield under a given set of management practices on mustard in central alluvial tract of Uttar Pradesh.

\section{Materials and Methods}

The experiment was conducted during rabi season of 2017-18 in pot culture of Soil Science and Agricultural Chemistry of C S Azad University of Agriculture \& Technology, Kanpur in alluvial soil. Soil of the experimental plot was sandy loam in texture and slightly calcareous having organic carbon $0.32 \%$, total nitrogen $0.03 \%$, available $\mathrm{P}_{2} \mathrm{O}_{5} 16.3 \mathrm{ha}^{-1}, \mathrm{pH} 7.7$, electrical conductivity $0.36 \mathrm{dSm}^{-1}$, permanent wilting point $6.3 \%$, field capacity $18.4 \%$, maximum water holding capacity $29.6 \%$, Bulk density $1.46 \mathrm{Mgm}^{-3}$, particle density $2.56 \mathrm{Mgm}^{-3}$ and porosity 42.9\%. The experiment was conducted in a randomized block design with three replications and nine treatments viz. $\mathrm{T}_{1}$ : Control, $\mathrm{T}_{2}$ : N (RDN 100\%), $\mathrm{T}_{3}$ : NP (100\%), $\mathrm{T}_{4}$ : NPK (100\%), $\mathrm{T}_{5}: \mathrm{NPK}(100 \%)+\mathrm{Zn}_{5}, \mathrm{~T}_{6}$ : $\mathrm{NPK}(100 \%)+\mathrm{S}_{30}, \mathrm{~T}_{7}$ : NPK $(100 \%)+\mathrm{Zn}_{5}+$ $\mathrm{S}_{30}, \mathrm{~T}_{8}: 75 \%(\mathrm{RDF})+\mathrm{Zn}_{5}+\mathrm{S}_{30}+25 \%$ through FYM and $\mathrm{T}_{9}: 75 \%(\mathrm{RDF})+\mathrm{Zn}_{5}+\mathrm{S}_{30}$ + 25\% through FYM + PSB @ $2.5 \mathrm{Kg} \mathrm{ha}^{-1}$ in soil. Mustard cv Varuna was sown in rows 45 $\mathrm{cm}$ apart using $5 \mathrm{~kg}$ seed ha ${ }^{-1}$ and harvested on 24.2.2018. Full dose of $\mathrm{P}$ and $\mathrm{K}$ while half dose of $\mathrm{N}$ was applied as basal dose at the time of sowing where rest of $\mathrm{N}$ was given in two split doses during experimentation. Available moisture at sowing time upto 100 $\mathrm{cm}$ soil profile was $277.3 \mathrm{~mm}$. Whereas amount of rainfall received during the crop period was nil against the average annual rainfall of about $800 \mathrm{~mm}$. Recommended package of practices were applied in different treatments. Soil moisture was monitored gravimetrically using the sample collected from 0-25, 25-50, 50-75 and 75-100 cm soil depths at regular monthly intervals to quantify 
the soil moisture content and growth parameters by randomly selecting three plants for each plots till the harvest. The amount of moisture used by the crop under different treatments was summing up the value of soil moisture depletion from the profile during the entire crop period. Water use efficiency (WUE) of the crop was calculated by the method as suggested by Viets (1962). The oil content of the oven dried seeds was estimated by extracting oil using petroleum ether (60$80^{\circ} \mathrm{C}$ ) as solvent and Soxhlet apparatus as given by Sadasivum and Manickam, (1992). The oil yield $\left(\mathrm{kg} \mathrm{ha}^{-1}\right)$ was calculated using following formula:

Oil yield $\left(\mathrm{kg} \mathrm{ha}^{-1}\right)=$ Seed oil content $(\%) \mathrm{x}$ Seed yield $\left(\mathrm{kg} \mathrm{ha}^{-1}\right)$

For economic evaluation the cost of cultivation, gross returns, net returns, and B:C ratio were computed using standard procedure based on minimum support price of Indian mustard. Root studies were made at harvest by selecting two plants at random from each plot. The roots were freed with a fine jet of water spray so that the delicate rootlets were not broken.

\section{Results and Discussion}

\section{Growth, yield attributes and yield}

The results of the present study indicated that growth, yield components and yield of mustard were significantly influenced by the different treatments as compared to control (Table 1). Plant height, number of functional leaves, number of branches, girth of plant, number of siliquae plant ${ }^{-1}$, number of seeds siliqua $^{-1}$, weight of siliqua, length of siliqua, 1000-seed weight and harvest index were significantly highest with application of $\mathrm{T}_{9}$ : $75 \%(\mathrm{RDF})+\mathrm{Zn}_{5}+\mathrm{S}_{30}+25 \%$ through FYM + PSB@ $@ 2.5 \mathrm{Kg} \mathrm{ha}^{-1}$ compared with control. The higher values of growth and yield attributes with organic and inorganic level might be due to supply of macro and micro nutrients in the balanced form resulting better growth and development of the plants Kumawat, (2010). Application of 75\% (RDF) + $\mathrm{Zn}_{5}+\mathrm{S}_{30}+25 \%$ through FYM + PSB @ 2.5 $\mathrm{Kg} \mathrm{ha}^{-1}$ in soil produced significantly higher values of growth and yield contributing characters over application of chemical fertilizer alone (Dhruw et al., 2017). Seed and straw yield of mustard was significantly affected due to nutrient management (Table 3). The significant increase in seed and stick + straw yield may be attributed to the positive effect of FYM supplemented with PSB in presence of chemical fertilizer resulting in consequent increase in yield components. The yield data obtained clearly demonstrate the superiority of the integrated use of FYM and chemical fertilizer, which provided greater response in production as compared to mineral $\mathrm{N}$ treatment. The beneficial effect of integrated use of nutrients with organic amendment was more pronounced and effective in enhancing productivity. This could be associated with other benefits of organics apart from $\mathrm{N}$ supply, such as improvements in microbial activities and better availability of plant nutrients from the soil (Singh et al., 2014). Increase in mustard yield due to FYM application has also been reported by Dabi et al., (2015). The significant increase in the yield as well as yield attributes may also be due to the fact that $50 \%$ flowering stage in Indian mustard is most sensitive stage in terms of nitrogen requirement and moisture availability to the crop results in increased water use efficiency and supply of critical nutrients. Furthermore, split dose of $\mathrm{N}$ as top dressing at this stage results in senescence delaying due to elongation of vegetative phase by retaining chlorophyll in the siliquae for longer period of time thereby resulting in improved attribute characteristics which resulted in more sink space and thus more photosynthesis transfer to the storage organs Kumari et al., (2012), Kumar et al., (2006) and Bharat et al., (2017). 


\section{Int.J.Curr.Microbiol.App.Sci (2018) 7(11): 2027-2034}

Table.1 Effect of INM on growth and development of mustard under different treatments

\begin{tabular}{|c|c|c|c|c|c|c|c|c|c|c|c|c|c|c|c|c|c|c|}
\hline \multirow[t]{3}{*}{ Treatments } & \multicolumn{4}{|c|}{ Plant Height $(\mathrm{cm})$} & \multicolumn{4}{|c|}{$\begin{array}{l}\text { Number of functional leaves } \\
\left.\text { (plant }{ }^{-1}\right)\end{array}$} & \multicolumn{6}{|c|}{ Number of branches (plant ${ }^{-1}$ ) } & \multicolumn{4}{|c|}{ Girth of plant $(\mathrm{cm})$} \\
\hline & \multirow{2}{*}{$\begin{array}{c}30 \\
\text { DAS }\end{array}$} & \multirow{2}{*}{$\begin{array}{c}60 \\
\text { DAS }\end{array}$} & \multirow{2}{*}{$\begin{array}{c}90 \\
\text { DAS }\end{array}$} & \multirow{2}{*}{$\begin{array}{c}\text { At } \\
\text { Harves } \\
\mathbf{t}\end{array}$} & \multirow{2}{*}{$\begin{array}{c}30 \\
\text { DAS }\end{array}$} & \multirow{2}{*}{$\begin{array}{c}60 \\
\text { DAS }\end{array}$} & \multirow{2}{*}{$\begin{array}{c}90 \\
\text { DAS }\end{array}$} & \multirow{2}{*}{$\begin{array}{c}\text { At } \\
\text { Harve } \\
\text { st }\end{array}$} & \multicolumn{3}{|c|}{ Primary } & \multicolumn{3}{|c|}{ Secondary } & \multirow[b]{2}{*}{$\begin{array}{c}30 \\
\text { DAS }\end{array}$} & \multirow[b]{2}{*}{$\begin{array}{c}60 \\
\text { DAS }\end{array}$} & \multirow[b]{2}{*}{$\begin{array}{c}90 \\
\text { DAS }\end{array}$} & \multirow[b]{2}{*}{$\begin{array}{c}\text { At } \\
\text { Harves } \\
\mathbf{t}\end{array}$} \\
\hline & & & & & & & & & $\begin{array}{l}\text { 60 } \\
\text { DAS }\end{array}$ & $\begin{array}{c}90 \\
\text { DAS }\end{array}$ & $\begin{array}{c}\text { At } \\
\text { Matur } \\
\text { ity }\end{array}$ & $\begin{array}{c}60 \\
\text { DAS }\end{array}$ & $\begin{array}{c}90 \\
\text { DAS }\end{array}$ & $\begin{array}{c}\text { At } \\
\text { Maturit } \\
\mathbf{y}\end{array}$ & & & & \\
\hline $\mathrm{T}_{1}$ & 23.1 & 69.8 & 105.6 & 106.8 & 6.87 & 8.97 & 12.08 & 10.09 & 5.34 & 7.56 & 13.07 & 8.30 & 13.30 & 15.39 & 4.3 & 6.2 & 8.0 & 9.0 \\
\hline $\mathrm{T}_{2}$ & 23.4 & 73.8 & 106.3 & 109.3 & 7.98 & 9.70 & 12.63 & 10.65 & 6.68 & 8.76 & 14.45 & 8.48 & 14.76 & 15.97 & 4.8 & 7.4 & 8.3 & 9.5 \\
\hline $\mathrm{T}_{3}$ & 22.5 & 69.9 & 104.3 & 110.0 & 8.45 & 9.98 & 12.87 & 11.78 & 5.97 & 9.35 & 15.38 & 9.54 & 14.65 & 16.67 & 5.0 & 7.8 & 8.7 & 10.2 \\
\hline $\mathrm{T}_{4}$ & 23.7 & 70.4 & 109.4 & 110.4 & 9.65 & 10.56 & 13.98 & 11.98 & 7.45 & 10.76 & 17.56 & 10.35 & 15.57 & 16.98 & 5.2 & 8.0 & 9.5 & 10.5 \\
\hline $\mathrm{T}_{5}$ & 23.9 & 71.8 & 110.0 & 111.2 & 10.87 & 11.87 & 14.87 & 12.86 & 7.98 & 10.12 & 17.98 & 11.36 & 16.78 & 17.89 & 5.6 & 8.3 & 9.7 & 10.7 \\
\hline $\mathrm{T}_{6}$ & 25.1 & 72.1 & 111.2 & 111.7 & 10.97 & 12.97 & 15.87 & 13.87 & 8.78 & 11.08 & 18.28 & 12.45 & 17.45 & 18.67 & 5.8 & 8.5 & 10.2 & 11.0 \\
\hline $\mathrm{T}_{7}$ & 25.9 & 72.5 & 112.7 & 112.9 & 11.67 & 14.87 & 16.78 & 14.07 & 8.92 & 12.46 & 18.48 & 13.56 & 18.56 & 19.97 & 6.3 & 8.8 & 10.6 & 11.2 \\
\hline $\mathrm{T}_{8}$ & 27.7 & 74.2 & 114.3 & 114.8 & 12.87 & 15.78 & 18.98 & 15.34 & 9.78 & 12.87 & 18.89 & 14.06 & 19.89 & 21.56 & 6.6 & 9.0 & 12.6 & 12.8 \\
\hline $\mathrm{T}_{9}$ & 29.6 & 77.3 & 117.5 & 118.0 & 13.87 & 17.89 & 20.32 & 17.45 & 11.23 & 13.98 & 19.88 & 15.87 & 21.87 & 23.00 & 7.0 & 9.5 & 13.0 & 13.5 \\
\hline $\mathrm{SE}(\mathrm{d})$ & 1.22 & 0.53 & 1.97 & 1.99 & 0.78 & 0.87 & 1.02 & 0.98 & 0.34 & 0.54 & 0.67 & 0.58 & 0.78 & 0.85 & 0.58 & 0.43 & 0.53 & 0.63 \\
\hline $\begin{array}{c}\mathrm{CD} \\
(\mathrm{P}=0.05)\end{array}$ & 2.59 & 1.12 & 4.67 & 4.76 & 1.45 & 1.76 & 2.17 & 1.97 & 0.69 & 1.02 & 1.45 & 1.34 & 1.56 & 1.75 & 1.19 & 0.96 & 1.23 & 1.24 \\
\hline
\end{tabular}

$\mathbf{T}_{1:}$ Control, $\mathbf{T}_{2:} N(R D N-100 \%), \mathbf{T}_{3:} N P(100 \%), \mathbf{T}_{4:} N P K(100 \%), \mathbf{T}_{5:} N P K(100 \%)+Z n_{5}, \mathbf{T}_{6:} N P K(100 \%)+S_{30,} \mathbf{T}_{7:} N P K(100 \%)+Z n_{5}+S_{30}$

$\mathbf{T}_{\mathbf{8}} 75 \%(R D F)+Z n_{5}+S_{30}+25 \%$ through FYM and $\mathbf{T}_{9:} 75 \%(R D F)+Z n_{5}+S_{30}+25 \%$ through FYM + PSB @ $2.5 \mathrm{~kg}$ ha ${ }^{-1}$ in soil. 


\section{Int.J.Curr.Microbiol.App.Sci (2018) 7(11): 2027-2034}

Table.2 Effect of INM on root development and yield attributes of mustard crop under different treatments

\begin{tabular}{|c|c|c|c|c|c|c|c|c|}
\hline Treatments & Root depth $(\mathrm{cm})$ & $\begin{array}{l}\text { No. of Roots } \\
\text { plant }^{-1}\end{array}$ & $\begin{array}{l}\text { Dry weight of } \\
\text { Roots }(\mathrm{g})\end{array}$ & $\begin{array}{l}\text { No. of siliquae } \\
\text { plant }^{-1}\end{array}$ & $\begin{array}{l}\text { No. of seeds } \\
\text { siliqua }\end{array}$ & $\begin{array}{l}\text { Weight of siliqua } \\
\text { (g) }\end{array}$ & $\begin{array}{l}\text { Length of siliqua } \\
\qquad(\mathrm{cm})\end{array}$ & $\begin{array}{l}\text { 1000-seed } \\
\text { weight }\end{array}$ \\
\hline $\mathrm{T}_{1}$ & 55.4 & 10.56 & 21.76 & 86.95 & 11.87 & 14.66 & 3.5 & 3.98 \\
\hline $\mathrm{T}_{2}$ & 58.3 & 12.45 & 23.56 & 89.34 & 13.55 & 16.45 & 3.8 & 4.10 \\
\hline $\mathrm{T}_{3}$ & 58.7 & 13.56 & 24.87 & 97.34 & 13.98 & 16.98 & 4.0 & 4.56 \\
\hline $\mathrm{T}_{4}$ & 60.4 & 13.98 & 24.98 & 99.87 & 14.56 & 17.45 & 4.3 & 4.87 \\
\hline $\mathrm{T}_{5}$ & 61.5 & 15.45 & 25.67 & 100.34 & 15.67 & 18.45 & 4.7 & 5.18 \\
\hline $\mathrm{T}_{6}$ & 63.9 & 15.98 & 25.98 & 105.35 & 15.88 & 18.89 & 4.8 & 5.20 \\
\hline $\mathrm{T}_{7}$ & 64.6 & 16.34 & 26.78 & 107.45 & 16.57 & 18.99 & 5.2 & 5.40 \\
\hline $\mathrm{T}_{8}$ & 66.2 & 16.88 & 27.78 & 110.45 & 18.45 & 19.45 & 5.4 & 5.65 \\
\hline $\mathrm{T}_{9}$ & 68.0 & 18.45 & 29.00 & 113.56 & 19.67 & 19.87 & 5.8 & 5.98 \\
\hline SE (d) & 0.18 & 0.53 & 0.75 & 0.56 & 0.34 & 0.56 & 0.06 & 0.07 \\
\hline $\mathrm{CD}(\mathrm{P}=0.05)$ & 0.36 & 1.17 & 1.51 & 1.24 & 0.69 & 1.14 & 0.12 & 0.14 \\
\hline
\end{tabular}

$\mathbf{T}_{1:}$ Control, $\mathbf{T}_{2:} N(R D N-100 \%), \mathbf{T}_{3:} N P(100 \%), \mathbf{T}_{4:} N P K(100 \%), \mathbf{T}_{5:} N P K(100 \%)+Z n_{5}, \mathbf{T}_{6:} N P K(100 \%)+S_{30}$

$\mathbf{T}_{7:} N P K(100 \%)+Z n_{5}+S_{30}, \mathbf{T}_{\mathbf{8}}: 75 \%(R D F)+Z n_{5}+S_{30}+25 \%$ through FYM and

$\mathbf{T}_{\mathbf{9}} 75 \%(R D F)+Z n_{5}+S_{30}+25 \%$ through FYM + PSB @ $2.5 \mathrm{~kg} \mathrm{ha}^{-1}$ in soil. 


\section{Int.J.Curr.Microbiol.App.Sci (2018) 7(11): 2027-2034}

Table.3 Effect of INM on yield, WUE and economics of mustard under different treatments

\begin{tabular}{|c|c|c|c|c|c|c|c|c|c|c|}
\hline Treatments & $\begin{array}{l}\text { Seed yield } \\
\quad\left(\mathrm{q} \mathrm{ha} \mathrm{ha}^{-1}\right)\end{array}$ & $\begin{array}{c}\text { Stick } \\
\left(\mathrm{q} \mathrm{ha} \mathrm{h}^{-1}\right)\end{array}$ & $\begin{array}{l}\text { Straw } \\
\left(\mathrm{q} \mathrm{ha}^{-1}\right)\end{array}$ & $\begin{array}{c}\text { Harvest } \\
\text { index }(\%)\end{array}$ & Oil (\%) & $\begin{array}{l}\text { Oil Yield } \\
\left(\mathrm{q} \mathrm{ha}{ }^{-1}\right)\end{array}$ & $\begin{array}{l}\text { WU } \\
(\mathrm{mm})\end{array}$ & $\begin{array}{c}\text { WUE } \\
\text { (Kg seed } \\
\mathrm{mm}^{-1} \mathrm{ha}^{-1} \\
\text { of water) }\end{array}$ & $\begin{array}{c}\text { Net } \\
\text { return } \\
\left(\mathrm{Rs} \mathrm{ha}^{-1}\right)\end{array}$ & $\begin{array}{l}\mathrm{B}: \mathrm{C} \\
\text { ratio }\end{array}$ \\
\hline $\mathrm{T}_{1}$ & 17.05 & 45.23 & 19.05 & 26.52 & 36.57 & 623.5 & 297.0 & 5.74 & 13171 & 1.34 \\
\hline $\mathrm{T}_{2}$ & 17.56 & 45.98 & 19.56 & 26.79 & 37.16 & 652.5 & 295.2 & 5.94 & 12007 & 1.36 \\
\hline $\mathrm{T}_{3}$ & 18.45 & 46.97 & 20.46 & 27.37 & 37.89 & 699.0 & 293.7 & 6.28 & 14619 & 1.39 \\
\hline $\mathrm{T}_{4}$ & 18.66 & 47.08 & 20.66 & 27.55 & 38.00 & 709.0 & 292.3 & 6.39 & 14457 & 1.40 \\
\hline $\mathrm{T}_{5}$ & 18.98 & 48.87 & 20.98 & 27.17 & 38.75 & 735.4 & 291.4 & 6.51 & 14984 & 1.41 \\
\hline $\mathrm{T}_{6}$ & 19.56 & 49.96 & 21.56 & 27.35 & 39.47 & 772.0 & 290.8 & 6.72 & 16558 & 1.43 \\
\hline $\mathrm{T}_{7}$ & 20.00 & 50.87 & 22.00 & 27.44 & 41.84 & 836.8 & 289.4 & 6.91 & 16217 & 1.44 \\
\hline $\mathrm{T}_{8}$ & 20.73 & 51.89 & 22.73 & 27.78 & 42.74 & 886.0 & 287.3 & 7.21 & 16121 & 1.48 \\
\hline $\mathrm{T}_{9}$ & 21.00 & 52.02 & 23.00 & 28.00 & 43.26 & 908.4 & 286.7 & 7.32 & 19279 & 1.49 \\
\hline SE (d) & 0.67 & 0.53 & 0.32 & 0.08 & 0.34 & 1.98 & - & - & - & - \\
\hline $\mathrm{CD}(\mathrm{P}=0.05)$ & 1.34 & 1.07 & 0.65 & 0.17 & 0.69 & 3.97 & - & - & - & - \\
\hline
\end{tabular}

$\mathbf{T}_{1:}$ Control, $\mathbf{T}_{2:} N(R D N-100 \%), \mathbf{T}_{3:} N P(100 \%), \mathbf{T}_{\mathbf{4}} N$ P K (100\%), $\mathbf{T}_{5:} N P K(100 \%)+Z n_{5}, \mathbf{T}_{6:} N P K(100 \%)+S_{30}$

$\mathbf{T}_{7:} N P K(100 \%)+Z n_{5}+S_{30}, \mathbf{T}_{\mathbf{8}}: 75 \%(R D F)+Z n_{5}+S_{30}+25 \%$ through FYM and

$\mathbf{T}_{\mathbf{9}}: 75 \%(R D F)+Z n_{5}+S_{30}+25 \%$ through FYM + PSB @ $2.5 \mathrm{~kg} \mathrm{ha}^{-1}$ in soil. 


\section{Root development}

There exists a well marked difference in the root development under different treatments. The deeper penetration of roots as measured by root depth was maximum $(68 \mathrm{~cm})$ in the treatment of T9 which received $75 \%(\mathrm{RDF})+$ $\mathrm{Zn}_{5}+\mathrm{S}_{30}+25 \%$ through FYM + PSB @ 2.5 $\mathrm{Kg} \mathrm{ha}^{-1}$ in soil while treatment of control exhibited shallow root $(55.4 \mathrm{~cm})$ system. The number of roots plant ${ }^{-1}$ and dry root weight were higher in $\mathrm{T}_{9}$ over control (Table 2). Similar observation has also been recorded by Tripathi et al., (2011).

\section{Water use and water use efficiency}

Water use was considerably influenced by different treatments. As a result the water use of crop was maximum $(297.0 \mathrm{~mm})$ under control while treatment of $\mathrm{T}_{9}$ revealed the lowest $(286.7 \mathrm{~mm})$ amount of water use. A higher WUE $\left(7.32 \mathrm{Kg}\right.$ seed $\left.\mathrm{ha}^{-1} \mathrm{~mm}^{-1}\right)$ in terms of seed yield per unit of water was obtained in the treatment of $\mathrm{T}_{9}$ where $\mathrm{FYM}$ and biofertilizers was used in integration with inorganics and lowest $\left(5.74 \mathrm{Kg}\right.$ seed $\mathrm{ha}^{-1}$ $\mathrm{mm}^{-1}$ ) under control. This was primarily due to higher seed yield under the former as compared to the latter. These observations are in line with those of Verma and Yadav, (2018).

\section{Economics}

The gross, net returns and benefit : cost ratio were affected by nutrient management treatments. Treatment of $75 \%$ (RDF) $+\mathrm{Zn}_{5}+$ $\mathrm{S}_{30}+25 \%$ through FYM + PSB @ $2.5 \mathrm{Kg} \mathrm{ha}$ ${ }^{1}$ in soil resulted in highest net returns of Rs 19279 with B:C ratio of 1.49 whereas these parameters were lowest under control. Higher productivity may be attributed to the positive effect of FYM supplemented with PSB in presence of chemical fertilizer. Thaneshwar et al., (2017) reported highest monetary advantage due to increase in yield with addition to balance form of nutrients in mustard.

From the foregoing discussion it can be concluded that application of $75 \%$ (RDF) + $\mathrm{Zn}_{5}+\mathrm{S}_{30}+25 \%$ through FYM + PSB @ 2.5 $\mathrm{Kg} \mathrm{ha}^{-1}$ incorporated in the soil have fetched highest net return of Rs 19279 having B:C ratio of 1.49 would be quite remunerative for higher productivity along with water use efficiency in light textured alluvial soils of Uttar Pradesh.

\section{Acknowledgement}

Authors are highly thankful to Professor and Head Department of Soil Science and Agricultural Chemistry and Dean College of Agriculture, C S Azad University of Agriculture \& Technology for providing all necessary facilities.

\section{References}

Bharat, R., Arya, V.M., Sharma, V., Kour, S., Gupta, Meenakshi, Sharma, V., Rai, S.K. and Gupta, R., 2017. Influence of agrochemicals on moisture stress mitigation in Indian mustard under rainfed conditions of Jammu. Journal of Soil and Water Conservation, 16 (3): 274-278.

Dabi, Bater; Singh, J.K., Singh, Rajesh, Kumar; Vishwakarma, Akhilesh, 2015. Quality and profitability of Indian mustard (Brassica juncea) as affected by nutrient-management practices under irrigated condition. Indian Journal of Agronomy, 60 (1):168-171.

Kumawat, A., Yadav, R.S. and Pareek, N.K., 2018. Residual effect of FYM and fertilizers on soil fertility, productivity and economics of pearl millet (Pennisetum glaucum L.). Journal of Soil and Water Conservation, 17 
(11):102-106.

Sadasivum, S.A. and Manickam, (1992). Biochemical methods for Agricultural Sciences. Wiley Eastern Ltd., New Delhi India, 187-188.

Singh, Shailendra,; Yadav, A. S. and Srivastava, D. S., 2014. Productivity, water use efficiency and economics of Indian mustard (Brassica juncea L.) as influenced by various fertility levels and mulching under rainfed condition. Journal of Soil and Water Conservation, 13 (2):181-183.

Thaneshar, Singh; Vishram, Prakash; Jai, Kumar, Manoj; Kumar, Sateesh and Singh, R.K., 2017. Effect of Integrated Nutrient Management on Growth and Yield of Mustard (Brassica juncea L.) in Irrigated Condition of Upper Gangetic Plain Zone of India. International Journal of Current Microbiology and Applied Sciences, 6 (1): 922-932.

Tripathi, M. K., Chaturvedi, S., Shukla, D.K., And Saini, S.K., 2011. Influence of integrated nutrient management on growth, yield and quality of Indian mustard (Brassica juncea L.) in tarai region of northern India. Journal of Crop and Weed, 7 (2): 104-107.

Verma, Amar Kant and Yadav, P.N., 2018. Productivity and water-use efficiency of linseed (Linum usitatissimum L.)-based cropping systems as influenced by integrated nutrient management under rainfed condition. Journal of Soil and Water Conservation, 17 (1): 53-57.

Viets, F.G., 1962. Fertilizers and efficient use of water. Advances in Agronomy, 14: 223-264.

Dhruw, Soman Singh; Swaroop, Narendra; Swamy, Akash and Upadhayay, Yogesh, 2017. Effects of Different Levels of NPK and Sulphur on Growth and Yield Attributes of Mustard (Brassica juncea L.) Cv. Varuna. International Journal of Current Microbiology and Applied Sciences, 6 (8): 1089-1098.

Kumari, Archana; Singh, R.P. and Yeshpal, 2012. Productivity, nutrient uptake and economics of mustard hybrid (Brassica juncea) under different planting time and row spacing. Indian Journal of Agronomy, 57 (1)-61-67.

Kumar, Naresh; Singh, Sandeep and Singh, Vinay, 2006. Effect of iron and sulphur levels on yield, oil content and their uptake by Indian mustard (Brassica juncea). Indian Journal of Agronomy, 51 (1):63-64.

Kumawat, B.S. 2010. Integrated nutrient management in black gram (Vigna mungo) and its residual effect on succeeding mustard (Brassica juncea L.) crop. Indian Journal of Agricultural Sciences, 80: 76-79.

\section{How to cite this article:}

Rahul Ranjan, Sushil Dimree, R.K. Pathak, U.D. Awasthi and Amar Kant Verma. 2018. Productivity, Water Use Efficiency and Economics of Indian Mustard (Brassica juncea L.) as Influenced by Integrated Nutrient Management. Int.J.Curr.Microbiol.App.Sci. 7(11): 20272034. doi: https://doi.org/10.20546/ijcmas.2018.711.230 